\title{
閉塞性黄疸例に拈ける耐糖能とインシュリン反応
}

\author{
横市市立大学第 2 外科 \\ 小林 衛 嶋田 紘 新明紘一郎 \\ 池田 義雄 米沢 健 土屋 周二

\section{GLUCOSE TOLERANCE AND INSULIN RESPONSES IN OBSTRUCTIVE JAUNDICE}

\section{Mamoru KOBAYASHI, Hiroshi SHIMADA, Kooichiro SHINMYO, Yoshio IKEDA, Takeshi YONEZAWA and Shuuji TSUCHIYA} \\ Second Department of Surgery, Yokohama City University School of Medicine
}

\begin{abstract}
閉塞性黄疸25例（対照10例）飞経口的 GTT (50g) を扣こなった．黄疸例の耐糖能は低下し，糖尿病型 を示するのは60\%に達し，insulinogenic index, 120分 $\Delta \mathrm{IRI} / \Delta \mathrm{BS}$ は対照例の1/2以下であった。黄疸の原 因疾患の種類，血清ビリルビン值，血清 $\mathrm{K}$ 値，年龄の各因子之耐糖能低下，インシュリン反応低下とを関 連づけることはできなかった．黄疸例，対照例ともに，GTT 時血中セロトニン,アドレナリン，ノルア ドレナリン值は正常範囲以上の変動を示するのがあったが，とくに黄疸例のセロトニン変動にこの傾向が 強かった. 胆管閉塞解除後 3 週間では，耐桾能およびインシュリン反応の改善はみられなかった。
\end{abstract}

語用引索 閉塞性黄庭, 耐楉能, インシュリン反応, セロトニン, カテコールアミン

\section{1. 結 論}

肝は生体全体の代謝の中心的役割を果して扣り，糖代 謝は肝に強く依存しているといってよい.したがって肝 炎や肝硬变など肝障害時に糖代謝が障害されることは当 然予測される。実際, 肝炎や肝硬変に和ける耐糖能を調

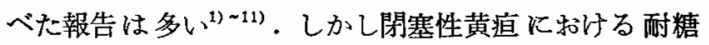
能を検討した研究は少ない ${ }^{12213)}$.そこでわれわれは開塞 性黄疸例 のブドウ糖負荷試験 (以下 GTT) による 耐糖 能、インシェリン反応を検討した．また GTT 時に消化 管アミン, カテコールアミンが変化するといわれており 13)，一部の症例には上記アミン類を測定し，若干の知見 を壳たので報告する。

\section{2. 対象と方法}

血清ビリルビン值 $3 \sim 41.5 \mathrm{mg} / \mathrm{dl}$ 以上の閉塞性黄疸25 例（膵頭部癌11例, 胆管癌 6 例, 胆石症 8 例）を対象と して, GTT (50g) を扣こない，120分まで末梢静脈より 採血し, autoanalyzer 法により血糖，二抗体法により immunoreactive insulin (以下 IRI) を测定した。セ口
トニンは contractor 法, アドレナリン，ノルアドレナ リンは trihydroindole 法により測定した。な㧊肝障害の ない良性消化管疾患10例を対照として同様に GTTを括 こない, 比較した。

3. 成

1) 血糖曲線

閉塞性黄㾝25例の血糖曲線を日本糖尿病学会勧告值に 基づいて分類すると, 表 1 のように正常型 1 例, 境界型 9 例，糖尿病型15例（60\%）である，対照例は正常型 2 例, 境界型 8 例であり, 黄疸例の耐糖能低下が有意に認 められた。

表 1 閉塞性黄疸例の耐糖能

\begin{tabular}{c|c|c|c}
\hline & 正常型 & 境界型 & 糖㽷病型 \\
\hline $\begin{array}{c}\text { 閉塞性黄疸 } \\
\text { (25例) }\end{array}$ & 1 例 & 9 例 & $\begin{array}{c}15 \text { 例 } \\
(60 \%)\end{array}$ \\
\hline 対 $_{(10 \text { 例 })}$ 照 & 2 & 8 & $*$ \\
\hline
\end{tabular}

*日, $\mathrm{p}<0.05$ 
表 2 疾患別耐糖能

\begin{tabular}{c|c|c|c} 
& 正常型 & 境界型 & 糖尿病型 \\
\hline 膵頭部癌 & & 3 例 & 8 例 \\
\hline 胆 管 癌 & & 3 & 3 \\
\hline 胆 石 症 & 1 & 3 & 4 \\
\hline
\end{tabular}

疾患別に耐糖能をみると, 表 2 のように膵頭部癌11例 8 例, 胆管癌 6 例中 3 例, 胆石症 8 例中 4 例がそれぞれ 糖尿病型であり，膵頭部癌の耐糖能が低下しているよう にみえるが，統計学的には有意差はなかった。

次に耐糖能に影響をおよぼしていると考えられる黄㾝 の程度すなわら血清ビリルビン值, 血清 $\mathrm{K}$ 值, 年龃の各 因子について検討してみた。

表 3 のように, 血清ビリルビン $15 \mathrm{mg} / \mathrm{dl}$ 未満10例中 5 例, 15 以上 $30 \mathrm{mg} / \mathrm{dI}$ 未満 11 例中 8 例, $30 \mathrm{mg} / \mathrm{dI}$ 以上 4 例 中 2 例が糖尿病型であり，ビリルビン值と耐糖能との間 には関連はみられなかった。

表 3 血清ビリルビン值と耐糖能

\begin{tabular}{l|r|c|c}
\hline \hline & 正常型 & 境界型 & 糖㽷病型 \\
\hline$<15(\mathrm{mg} / \mathrm{dl})$ & 1 例 & 4 例 & 5 例 \\
\hline $15 \leqq<30$ & & 3 & 8 \\
\hline $30 \leqq$ & & 2 & 2 \\
\hline
\end{tabular}

表 4 血清 $\mathrm{K}$ 值と耐楉能

\begin{tabular}{l|c|c|c}
\hline & 正常型 & 境界型 & 糖尿病型 \\
\hline$\sim 3.5(\mathrm{mEq} / \mathrm{l})$ & & 2 例 & 4 例 \\
\hline $3.6 \sim 4.1$ & 1 & 5 & 5 \\
\hline $4.2 \sim$ & & 2 & 6 \\
\hline
\end{tabular}

血清 $\mathrm{K}$ 値は表 4 のように, $3.5 \mathrm{mEq} / 1$ 以下 6 例中 4 例, $3.6 \sim 4.1 \mathrm{mEq} / 111$ 例中 5 例, $4.2 \mathrm{mEq} / 1$ 以上 8 例中 6 例 が糖尿病型であり，血清K值と耐糖能との間には関連は みられなかった。

年秢別にみると, 表 5 のように49歳以下 5 例中 1 例， $50 \sim 59$ 歳 6 例中 4 例, $60 \sim 69$ 歳 8 例中 6 例, 70 歳以上 6 例中 4 例が糖尿病型であり，49歳以下の例の耐糖能が良 好のようにみえるが，統計学的には有意差はなく，年龄 と耐糖能との間には関連はなかった。

2) インシュリン反応

インシュリン反応をみる一法として，30分 $\Delta \mathrm{IRI} / \Delta \mathrm{BS}$ (insulinogenic index 以下 I.I) と 120 分 $\Delta \mathrm{IRI} / \Delta \mathrm{BS}$ (以
表 5 年令と耐糖能

\begin{tabular}{c|r|c|c}
\hline \hline & 正常型 & 境界型 & 糖尿病型 \\
\hline$\sim 49$ 歳 & 1 例 & 3 例 & 1 例 \\
\hline $50 \sim 59$ & & 2 & 4 \\
\hline $60 \sim 69$ & & 2 & 6 \\
\hline $70 \sim$ & & 2 & 4 \\
\hline
\end{tabular}

下 I/G)をとった。

閉塞性黄疸25例の I.I の平均値は表6のように, $0.197 \pm 0.056$ であり, 対照10例の平均値0.502士0.062 と 比べて有意に低かった。

また黄㡺25例の $\mathrm{I} / \mathrm{G}$ の平均値は0.293土0.074であり, 対照10例 の平均値0.824士0.132に比べて有意に低かっ た。

疾患別にみると表7のよらに, 膵頭部癌11例の I.I の 平均值は $0.227 \pm 0.077, \mathrm{I} / \mathrm{G}$ の平均値は $0.265 \pm 0.128$, 胆管癌 6 例は $0.043 \pm 0.111,0.214 \pm 0.079$, 胆石症 8 例

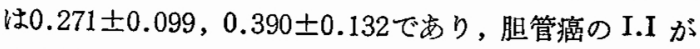
やや低いよらであるが, 統計学的には有意差はなかっ た。

表 6 閉塞性黄疾例のインシュリン反応

\begin{tabular}{|c|c|c|}
\hline & $\begin{array}{l}\text { insulinogenic } \\
\text { index } \\
(\mathrm{M} \pm \mathrm{SE} \text { ) }\end{array}$ & $\begin{array}{c}120 / 3 \\
\Delta \mathrm{IRI} / \Delta \mathrm{BS} \\
(\mathrm{M} \pm \mathrm{SE})\end{array}$ \\
\hline 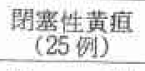 & $0.197 \pm 0.056^{*}$ & $0.293 \pm 0.074^{*}$ \\
\hline${ }_{(10 \text { 例 })^{\text {明 }}}$ & $0.502 \pm 0.062^{\circ}$ & $0.824 \pm 0.132 *$ \\
\hline
\end{tabular}

表 7 疾患別インシュリン反応

\begin{tabular}{c|c|c}
\hline \hline & $\begin{array}{c}\text { insulinogenic } \\
\text { index } \\
(\mathrm{M} \pm \mathrm{SE})\end{array}$ & $\begin{array}{c}120 \text { 分 } \\
(\mathrm{IRI} / \mathrm{SBS} \\
(\mathrm{M} \pm \mathrm{SE})\end{array}$ \\
\hline $\begin{array}{c}\text { 膵頭部癌 } \\
(11 \text { 例 })\end{array}$ & $0.227 \pm 0.077$ & $0.265 \pm 0.128$ \\
\hline $\begin{array}{c}\text { 胆 管癌 } \\
(\text { 6例 })\end{array}$ & $0.043 \pm 0.111$ & $0.214 \pm 0.079$ \\
\hline $\begin{array}{c}\text { 胆 石症 } \\
(\text { 8例 })\end{array}$ & $0.271 \pm 0.099$ & $0.390 \pm 0.132$ \\
\hline
\end{tabular}

血清ビリルビン值からみると, 表 8 のように $15 \mathrm{mg} / \mathrm{dl}$ 末満の 10 例の I.I 平均値は $0.223 \pm 0.085, \mathrm{I} / \mathrm{G}$ の平均 值は0.341士0.111，15以上 $30 \mathrm{mg} / \mathrm{dl}$ 末満11例は0.166士 $0.098,0.232 \pm 0.131,30 \mathrm{mg} / \mathrm{dl}$ 以上 4 例は $0.215 \pm$ $0.072,0.339 \pm 0.073$ であり，3群に統計学的有意差は なかった。 
表 8 血清ビリルビン值とインシュリン反応

\begin{tabular}{|c|c|c|}
\hline & $\begin{array}{l}\text { insulinogenic } \\
\text { index } \\
(\mathrm{M} \pm \mathrm{SE})\end{array}$ & $\begin{array}{c}120 \text { 分 } \\
\Delta I R I / \Delta B S \\
(M \pm S E)\end{array}$ \\
\hline $\begin{array}{c}<15(\mathrm{mg} / \mathrm{dl}) \\
(10(\text { yij })\end{array}$ & $0.223 \pm 0.085$ & $0.341 \pm 0.111$ \\
\hline $15 \leqq<30$ & $0.166 \pm 0.098$ & $0.232 \pm 0.131$ \\
\hline 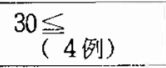 & $0.215 \pm 0.072$ & $0.339 \pm 0.073$ \\
\hline
\end{tabular}

表 9 血清K値とインシュリン反応

\begin{tabular}{|c|c|c|}
\hline & $\begin{array}{l}\text { insulinogenic } \\
\text { index } \\
(\mathrm{M} \pm \mathrm{SE})\end{array}$ & $\begin{array}{c}120 \text { 筮 } \\
4 \mathrm{IRI} B \mathrm{BS} \\
(\mathrm{M} \pm \mathrm{SE})\end{array}$ \\
\hline $\begin{array}{c}-3.5(\mathrm{mEq} / 1) \\
(6 \text { 利 })\end{array}$ & $0.042 \pm 0.111$ & $0.187 \pm 0.085$ \\
\hline $\begin{array}{c}3.6 \sim 4.1 \\
(11 \text { 例 })\end{array}$ & $0.274 \pm 0.094$ & $0.295 \pm 0.107$ \\
\hline $4.2 \sim(8$ 泀) & $0.207 \pm 0.061$ & $0.367 \pm 0.163$ \\
\hline
\end{tabular}

表10 年令とインシュリン反応

\begin{tabular}{r|r|c}
\hline \hline & $\begin{array}{c}\text { insulinogenic } \\
\text { index } \\
(\mathrm{M} \pm \mathrm{SE})\end{array}$ & $\begin{array}{c}120 \text { 公 } \\
\text { (IRI/ABS } \\
(\mathrm{M} \pm \mathrm{SE})\end{array}$ \\
\hline$\sim 49$ & $0.371 \pm 0.146$ & $0.755 \pm 0.258$ \\
\hline $50 \sim 59$ & $-0.008 \pm 0.096$ & $0.142 \pm 0.048$ \\
\hline $60 \sim 69$ & $0.170 \pm 0.096$ & $0.093 \pm 0.027$ \\
\hline $70 \sim$ & $0.293 \pm 0.040$ & $0.337 \pm 0.047$ \\
\hline
\end{tabular}

血清K值からみると, 表 9 のように $3.5 \mathrm{mEq} / 1$ 以下 6 例の I.I の平均値は $0.042 \pm 0.111, \mathrm{I} / \mathrm{G}$ の平均値は $0.187 \pm 0.085,3.6 \sim 4.1 \mathrm{mEq} / 111$ 例は $0.274 \pm 0.094$, $0.295 \pm 0.107,4.2 \mathrm{mEq} / 1$ 以上 8 例は0.207士0.061, $0.367 \pm 0.163$ であり，血清 $\mathrm{K}$ 值 $3.5 \mathrm{mEq} / 1$ 以下の I.I が 低いようであるが, 統計学的には有意差はなかった。

年齡別にみると表10のように，49歳以下 5 例の II の 平均值は0.371土0.146, $\mathrm{I} / \mathrm{G}$ の平均値は $0.755 \pm 0.258$, $50 \sim 59$ 歳 6 例は $-0.008 \pm 0.096,0.142 \pm 0.048,60 \sim 69$ 歳 8 例は0.170士0.096, $0.093 \pm 0.027,70$ 歳以上 6 例は $0.293 \pm 0.040,0.337 \pm 0.047$ あ゙す，49藏以下のインシ ニリン反応は高いよらであるが，4群に統計学的有意差 はなかった。

3） GTT 時のセロトニン,カテコールアミンの変動 閉塞性黄疸 6 例と対照 4 例に血中セロトニンを測定し た. 図1のように，黄疸例ではすべての症例が空腹時の 值から正常範囲以上の高値を示し, 糖負荷後も高値で変 動した. 対照例は図 2 のよらに, 半数の症例が正常範囲
因 1 閉塞性黄㾝例

セロトニン，カテコールアミンの变動
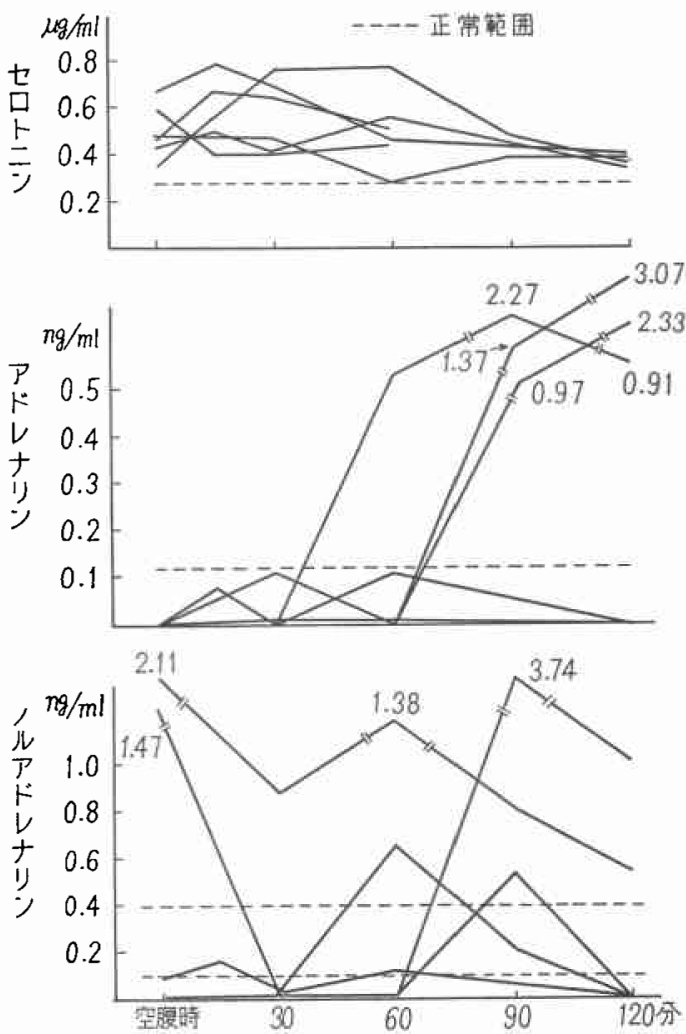

外の変動を示したにすぎなかった。

アドレナリン，ノルアドレナリンは閉塞性黄疸 5 例, 対照 4 例に測定した. カテュールアミンは黄疸例も刘照 例子過半数の症例が正常範囲外飞逸脱して増減した。な お著しい高值を示す例もあったが，黄疽例に特有のパ ターンをみいたすすことはできなかった。

4）胆管閉塞解除後の耐糖能, インシュリン反応の変 化

25例中11例に胆管閉塞解除後 3 週前後で, 同様の GTTを施行し，解除前と比較した。

血糖曲線の分類は表11のように, 解除前11例中 7 例が 糖尿病型を示したが, 解除後は 3 例に減少した. しか し、これは統計学的有意差とはいえなかった。

I.I の平均値は, 解除前 $0.274 \pm 0.078$ 之解除後 $0.288 \pm$

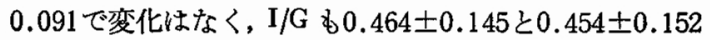
で変化は認められなかった。

\section{4. 考 察}

肝臓は生体の糖代謝上重要な役割を果している関俰 
表11 胆管閉塞解除前後の耐楉能とインショリン反応（11例）

\begin{tabular}{|c|c|c|c|c|c|}
\hline & 正常型 & 境界型 & 榶尿病型 & $\begin{array}{l}\text { insulinogenic } \\
\text { index } \\
(\mathrm{M} \pm \mathrm{SE})\end{array}$ & 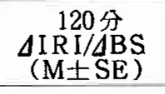 \\
\hline 解除前 & 1例 & 3 例 & 7例 & $0.274 \pm 0.078$ & $0.464 \pm 0.145$ \\
\hline $\begin{array}{l}\text { 解除後 } \\
\text { (3週) }\end{array}$ & 1 & 7 & 3 & $0.288 \pm 0.091$ & $0.454 \pm 0.152$ \\
\hline
\end{tabular}

図 2 対照例

セロトニン, カティールアミンの变動
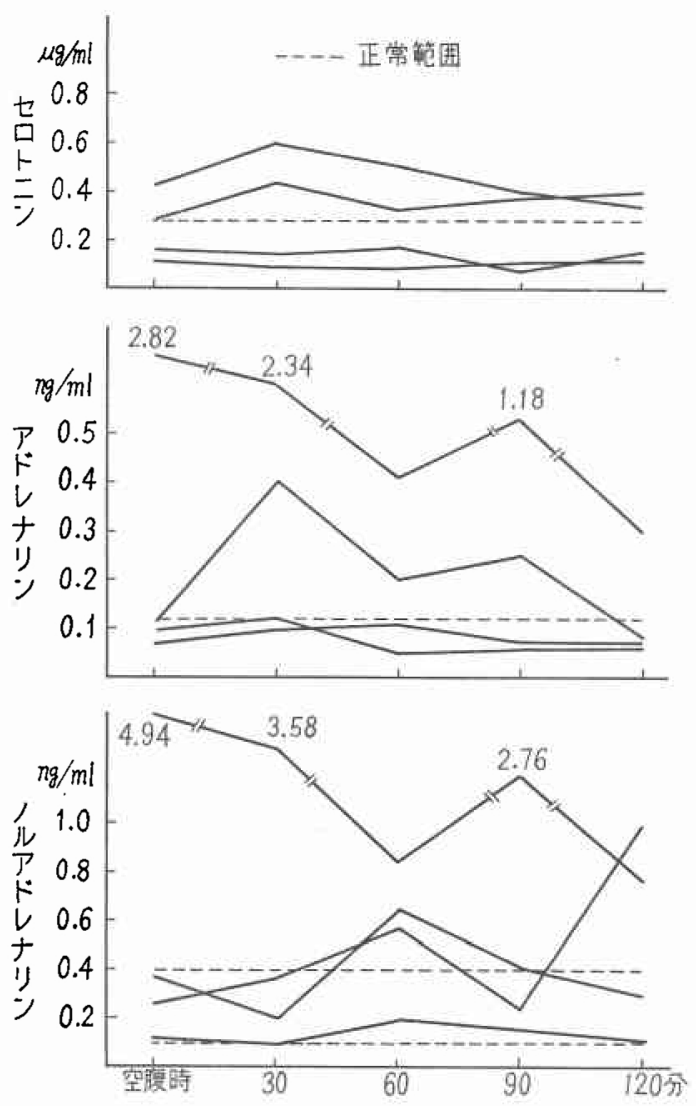

上，肝障害時には糖代謝に異常をさたすことはよく知ら れている。事実，肝炎や肝硬変の肝障害例の耐糖能低下 は多く報告されているい 炎では30〜70\%に，肝硬変では70～90\%に GTT による

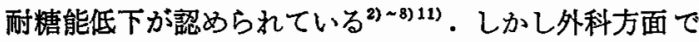
取扱う閉塞性黄疾に和ける糖代謝の研究は少ない(2)13).

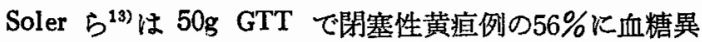
常をみている。われわれの25例でも60\%と，ほぼ同率の
耐糖能低下を示した。

一方, GTT 時のインシュリン反応をみる方法として, Seltzer ら ${ }^{15}$ は120分間に増量した血糖に対する増量 IRI の比を insulinogenic index として表わしたが，最近は 30 分の $\Delta \mathrm{IRI} / \Delta \mathrm{BS}$ が糖尿病と非糖尿病の鑑別に有用で あり、これを insulinogenic index と表現することが多 (1116) 19).この表現法による insulinogenic index を文 献的にみると，急性肝炎0.93〜1.006, 僈性肝炎0.9 1.891 , 肝硬変 $0.59 \sim 0.891$, 軽度糖尿病0.142 0.44, 重症糖尿病0.09, 正常0.8〜1.656とされている(10)1117) 19) •わわれの対照例の insulinogenic index は0.501と 前述の報告者の値と比べて低值である．この理由は不明 であるが，閉塞性黄疸25例の平均値は0.197 と有意低 かった. 䀒资や肝硬変に括いては正常例の insulinogenic index とあまり変らない值を示しているのに対し，閉塞 性黄㾞例の index は非常に低值で, 糖㽷病に似ており。 前述の肝炎, 肝硬変と異なった型とい党る。

次に120分 $\Delta I R I / \Delta B S$ にいてまると, Seltzer ら 軽度糖疗病 2.43 , 正常4.93としており，前者は後者の約 1/2である.われわれの成績でる正常0.824に対して，閉 塞性黄疾例は0.292 と有意に低く,インシェリン反応低 下が示された。

次に閉塞性黄疸例の疾患別に耐糖能，インシュリン反 応をみると, Soler ら ${ }^{\text {(3) }}$ は膵癌はその他の閉塞性黄㾝例 に比ぺて 耐糖能は同程度であるが,インシュリンは低 く，またその反応す遅いと述べている.しかしわれわれ は脺頭部癌, 胆管癌, 胆石症の 3 群に分けて検討した が, 耐糖能，インシュリン反応に有意差はみられなかっ た。

糖代謝は年龄に関係し，50歳以上では耐糖能が低下す るといわれているが ${ }^{13)}$ ，われわれの閉塞性黄疾例におい ては, 年龄と耐糖能、インシュリン反応との間に関係は みられなかった。一方実験的には，血清ビリルビン值の 高さに比例して，インシュリン分泌能は低下するといわ れているが20)，われわれの閉塞珄黄疸例では血清ビリル 
ビン值から 3 群に分けて検討したが，耐糖能およびイン シュリン反応に有意差はみられなかった。

他方, 肝硬変例では血清K值は正常でも, 全身のK值は 低いことがあると述べられている 黄㾝25例中 6 例のみが低K血症を示したが，潜在的には もっと多くの症例に低K血症が存在する可能性はある．

また血清Kがインシュリン分泌を刺激することは実験的 に認められて衫り ${ }^{2223)}$ ，さらに臨本的にも低K血症を呈 する肝硬変症に $\mathrm{KCl}$ を投与することより，血清 $\mathrm{K}$ 值 の上昇ととるに耐糖能，インシュリン反応の改善がみら れたといら ${ }^{24)}$ 。そこでわれわれる，血清K值から閉塞性 黄瘨例を 3 群に分けて検討したが，耐桾能，インシュリ ン反応と血清 $\mathrm{K}$ 値との間に関連をみいだすことはできな かった。

次に GTT 時の血中セロトニン, カテコールアミンの 変動を観察したが，セロトニンは GTT 時に正常範囲以 上に变化することが認められ，特に閉塞性黄庭例に扣い て，この傾向が著明であった。セロトニンの前駆物質で ある $5 \mathrm{HPT}$ はインシェリン分泌を刺激するが25)，七口 トニンは逆にインシュリン分泌を抑制するといわれてい る ${ }^{1425)}$. しかしこの作用はカテェールアミンを介しての 間接的作用であることも考党られる。いずれにしても GTT 時のセロトニン变動がインシュリン分泌飞影響を 与光て、インシュリン反応を抑制している可能性があ る.

アドレナリン，ノルアドレナリンは $\alpha$-受容体機構を介 してインシュリン分泌抑制, $\beta$-受容体機構を介して分泌 刺激するといわれているが2627)，一般には $\alpha$-受容体の方 が強力で，インシュリン分泌抑制作用がある. Rober tson $ら^{28)}$ は $\alpha$-blocker である phentolamine の使用によ り，インシニリン反応のなかった糖尿病症例にインシュ リン反応をみて括り，その間の血中カテコールアミン值 は正常群より有意に高かったと報告している。このよう Kカテュールアミンがインシュリン分泌影響を拉よぼ しているのは事実であるらが，われわれの閉塞珄黄疸， 対照例ともに GTT 時にカテュールアミンのかなりの变 動をみたるのの，黄㾝例に特異な所見をみつけることは できなかった。

さて, 耐糖能とは負荷された糖がいかに利用されて, 血 糖上昇が防がれるかということを意味している。この糖 の利用とは，1）エネルギー獲得系，2）肝グリューダ ン合成系，3）脂肪酸合成系の 3 者であり ${ }^{29)}$ ，この 3 者 はいずれる嫌気性解糖系を経由しなければならない。こ
の解糖系酵素のなかの律速酵素は, hexokinase (glucokinase), phosphofructokinase, 㧊よび pyruvate kinase の 3つであり, 慢性肝炎, 肝硬変に乱いては glucokinase の低下が報告されている ${ }^{30)}$. た急性肝炎時には phosphohexoiomerase, aldolase, lactate dehydrogenase など の酛素㧊よび, isocitrate dehydrogenase, malate dehydrogenase など TCA サイクル酵素低下がみとめられて いる ${ }^{31)}$. 一方糖新生系醅素は解糖采酵素注它の強い変化 はないとされている ${ }^{31}$. 以上のべたように，肝障害時の 耐糖能異常は解桾系酵素の低下に一因を求めることはで きる.しかし前述の糖利用には直接，間接的にインシュ リンが関与している.肝炎や肝硬変例の insulinogenic index が正常例とあまり差がないことは，インシュリン の絶対量は增加していることを意味している(1)192)．こ の絶対量の増加の説明としては，1）膵からのインシニ リン分泌圥進，2）インシュリンの肝などに怙ける分解 能低下，の二つが考えられる１1)については，なんらか の原因によるインシュリン抵抗性穴進をたは解糖系䤃素 低下に対する膆インシュリン分泌の代償性反応とみるこ とができる.事実, 肝硬変症の膵組織検索上, ラ島の肥

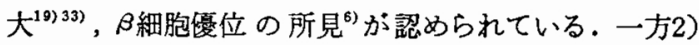
については，肝障害時の肝内外飞怙ける門脈副血行に よる短絡や肝のインシュリン分解酵素の低下によって, インシュリンが血中高值を保っている解释もある ${ }^{34)}$. Johnston ら ${ }^{35)}$ は c-ペプタイドの定量から, 肝硬変症の 高インシュリン血症は肝での分解能低下によると説明し ているが，現在のところ，どちらの説明が当をえたるの か断言はできない.われわれの閉塞性黄疸例の120分 $\Delta \mathrm{IRI} / \Delta \mathrm{BS}$ 汶対照例火比べて非常低く, 絶対量も低下 したことは, 肝炎や肝硬変症とは異なった型のインシュ リン反応ということができる.

なおインシュリン分泌には，視床下部腹内側核に始ま る交感神経，外側核に始をる副交感神経をはじめ，消化 管アミン，カテコールアミンとグルココルチコイド，セ クレチンや PZ-CCK など消化管ホルモン ${ }^{36) 97) ~}$ 分泌機能 ${ }^{38)}$ ，成長ホルモンや甲状腺ホルモン，ソマトス タチン ${ }^{391}$ やグルカゴン，プロスタグランジン $\mathrm{E}_{1}{ }^{40)}, \mathrm{AC}$ $\mathrm{TH}$ 電解質の $\mathrm{K}, \mathrm{Ca}$ と $\mathrm{P}^{41)}$ などが直接, 間接的に作用 しており，またインシュリン分解䣼素である glutathioninsulin transhydrogenase, insulinase, 肝や脂肪組織の細胞 膜インシュリン分解活珄 ${ }^{42)}$, 遊離脂肪酸などのインシュ リン拮抗物質, インシュリン抗体などが関与し, 複雑な メカニズムで統御されているようである。最近，各種細 
胞膜にインシニリン受容体が証明されて，これによって 細胞内に情報が伝わり，インシュリンの生理作用が発現 されると考学られている43).さらにこの受容体抗体の存 在によるインシュリン抵抗性が報告されている(4). 今後 の研究によって，この方面の機序が解明されることを期 待したい.

\section{5. 結 語}

閉塞性黄瘨25例（対照10例）に GTTをょこない，以 下の結論をえた。

1. 閉塞性黄疸例の耐糖能は低下し，糖㽷病型を示す ものが60\%を占めた. insulinogenic index, 120分 $\Delta I R I /$ $\triangle B S$ は対照例の1/2以下であった。

2. 閉塞性黄瘨の原因疾患, 血清ビリルビン値, 血清 $\mathrm{K}$ 值，年齢の各因子と耐糖能低下，インシュリン反応低 下とを関連づけることはできなかった。

3. 閉塞性黄疸例, 対照例ともに, GTT 時血中セ口 トニン,アドレナリン，ノルアドレナリン值は正常範囲 を越えて変動する例が認められた．特に閉塞性黄㾝例の セロトニン変動にこの傾向が強かった。

4. 胆管閉塞解除後 3 週間では, 耐糖能およびインシ ニリン反応の改善はみられなかった。

\section{文献}

1) Megyesi, C. et al.: Glucose tolerance and and diabetes in chronic liver disease. Lancet, 2: 1051-1055, 1967.

2) 增田正典他：䀒障害之糖代謝異常に関する臨床 的研究, 日本内科学会雑誌, 55 : 569-570, 1966 .

3) 川村耕造他：肝障害の進展と膵内分泌異常に関 する研究. 肝臓, 7 : 320-329, 1966 .

4) 和田正久:肝障害時の糖代謝異常, 糖尿, 11 : $263-267,1968$.

5）森 克己：いわゆる肝性糖尿病に関する 2,3 の検討, 榬尿病, $11: 267-274,1968$.

6) 小坂淳夫 他 : 肝疾患時に みられる糖代謝異常, 糖尿病, $11: 275-282,1968$.

7) 石井裕正 : 肝障害時の糖代謝異常に関する研究 1. 血糖調節異常におよぼす肝性ならびに膵性 因子の臨床的検討. 日本消化器病学会雑誌, 66: 361 -371, 1969.

8) 早川浩之：肝疾患における血中インシュリン動 態㥻与る研究, 日本消化器病学会雑誌, 67 : 457-468, 1970.

9) 小笠原徹也他: 肝疾患に括ける膵内分泌機能, とくに $\alpha$ 細胞機能に関する研究, 日本消化器病 学会雑誌, 74: 1042-1047, 1977.

10) 中车田健他：僈性肝疾患時の糖代謝に対する糖
質コルチコイドの影響，肝臓， 11：838-845， 1977.

11）高森成之他：インスリン動態よりみた肝障害時 の䅺代謝異常に関する研究, 肝臓, 9：615一 623, 1977.

12）小沢和恵他：肝障害一肝の代償性からみた機能 的予備力の把挃一, 外科, 36: 1092- 1098, 1974.

13) Soler, N.G. et al.: Carbohydrate tolerance and insulin responses in obstructive jaundice. Brit. Med. J., 4: 447-449, 1974.

14）池田義雄他：消化管アミンからみた術後糖代謝 異常, 術後代謝研究会誌, 11：109-113,1976.

15) Seltzer, H.S. et al.: Insulin secretion in response to glycemic stimulus: Intolerance in mild diabetes mellitus. J. Clin. Invest., 46: 323-335, 1967.

16)羽倉稜子他：糖尿病および非糖尿病飞おける glucose 負荷後の $\Delta \mathrm{IRI} / \Delta \mathrm{BS}$ に関する㭘討, 糖尿病 (Suppl) $15: 51,1972$.

17) Collins, J.R. et al.: Glucose intolerance and insulin resistance in patients with liver disease. Arch. Intern. Med., 124: 142-148, 1969.

18）清野 裕他：二次性糖尿病に打ける insulinogenic index について, 糖尿病, $17: 35-43$, 1974.

19) 石井裕正他：肝性楉代謝異常の病態生理. 肝 臓, 15: 103-106, 1974 .

20) 大柳治正他：閉塞性黄疸の病態生理と手術時期 についての検討, 日本消化器外科学会雑誌, 8: 211-219, 1975.

21) Soler, N.G. et al.: Potassium status of patients with cirrhosis. Gut, 17: 153-157, 1976.

22) Grodsky, G.M. et al.: Cation requirements for insulin secretion in the isolated perfused pancreas. Diabetes. 15: 910—913, 1966.

23) Howell, S.L. et al.: Potassium ions and the secretion of insulin by islet of Langerhans incubated in vitro. Biochem. J., 108: 17-24, 1968.

24) Podolsky, S. et al.: Potassium depletion in hepatic cirrhosis: A reversible cause of impaired growthhormon and insulin reponse to stimulation. New Eng. J. Med., 288: 644$648,1973$.

25) Gylfe, E. et al.: Amino-acid conversion into 5-hydroxy tryptamine in pancreatic B-cells. Endocr., 93: 932-937, 1973.

26) Porte, D. Jr. et al.: Inhibition of insulin release by norepinephrine in man. Science, 152: 1248-1250, 1966.

27) Porte, D. Jr. et al.: A receptor mechanism for the inhibition of insulin release by epinephrine in man. J. Clin. Invest., 46: 86- 
94, 1967.

28) Robertson, P. et al.: A role for alpha-adreneragic receptors in abnormal insulin secretion in diabetes mellitus. J. Clin. Invest., 57: 791-795, 1976.

29）宇井理生他：糖代謝 のホルモン性調節, 代謝, $13: 731-740,1976$.

30) 武田和久他：肝疾恵の耐糖能々肝 glucokinase おょび hexokinase 活性の関連について, 肝荿, $15: 115-117,1974$.

31）高橋忠雄, 織田敏次編集: 肝臓病 (医学書院), 東京, 64,1973 .

32）小坂樹恵他：血中インスリン測定の精尿病診断 への導入とその基礎, 日本臨床, 31 : 2218一 $2226,1973$.

33) 大坪守: 肝硬变, 肝癌尼飞拈ける勝組織学的 研究, 日本消化器病学会雜誌, 62:1089-1103, 1965.

34) 河村知矩 : インシニリンの化学と代謝, 代謝, 3 : $242-251,1966$.

35) Johnston, D.G. et al.: Hyperinsulinism of hepatic cirrhosis: Diminishid degradation or hypersecretion? Lancet, 1: 10-13, 1977.

36) Danielsson, A. et al.: Effects of pancreozymin and secretin on insulin release and the role of the exocrine pancreas. Diabetol., 10: 407409, 1974.
37) 藤田恒男: 胃腸膵ホルモンの栄養效果, 医学の あゆみ, 104：399-407, 1978.

38）仙波大右他：膵外一膵内分泌相関に関する実験 的研究, 外科治療, $38: 70,1978$.

39) Wahren, J. et al.: Influence of somatostatin on splanchnic glucose metabolism in postabsorptive and 60-hour fasted humans. J. Clin. Invest., 59: 299-307, 1977.

40) Bressler, R. et al.: Tranycypromine: A potent insulin secretagogue and hypoglycemic agent. Diabetes, 17: 618-624, 1968.

41) Harter, H.R. et al.: The relative roles of calcium, phosphorus, and parathyroid hormon in glucose and tolbutamide-mediated insulin release. J. Clin. Invest., 58: 359—367, 1976.

42) Freychet, P. et al.: Insulin interactions with liver plasma membrances. Independence of binding of the hormon and its degradation. J. Biol. Chemist., 247: 3953-3961, 1972.

43) Bur, R.S. et al.: Insulin receptors status in disease status of man. Arch. Int. Med., 137: $474-481,1977$.

44）河西浩一他 : Sjögren 症候群を合併し antiinsulin receptor autoantibodies によるインスリン 抵抗性榶尿病の 1 例々免度抑制治潦法の効果, 榶尿病, $19: 528-538,1976$. 